\title{
Pengaruh Kualitas Kehidupan Kerja dan Motivasi Kerja Terhadap Kinerja Karyawan
}

\author{
Nur Hasmalawati, Nida Hasanati \\ nurhasmalawati@gmail.com
}

Jurusan Sains Psikologi, Universitas Muhammadiyah Malang, Malang, Indonesia

\begin{abstract}
This study aims to determine the effect of Quality of Work Life $(Q W L)$ and work motivation on employee performance. Subjects in this study were 50 TB-HIV Cadres, consisting of 36 women and 14 men whose ages ranged from 18 to 63 years old. This study applied multiple linear regression in analyzing data obtained from Likert-scale questionnaires. The results show that the $Q W L$ is significantly influential on performance, with $R$ Square 0.313 and $p$ value 0.000, meaning that the QWL affects performance with $31 \%$ contribution. Meanwhile, the rest was influenced by other variables. However, work motivation seems to have no effect on performance $(p>0.05)$. The practical implication of this study would be the more the manager is taking care of their employee's QWL, the higher the performance of their employee will be. This subsequently may result in more productive employee in improving services to the society.
\end{abstract}

Penelitian ini bertujuan untuk mengetahui pengaruh kualitas kehidupan kerja atau Quality of Work Life (QWL) dan motivasi kerja terhadap kinerja karyawan. Subjek dalam penelitian ini adalah adalah Kader TB-HIV yang berjumlah 50 orang, terdiri dari 36 orang perempuan dan 14 orang laki-laki dengan rentang usia antara 18-63 tahun. Penelitian ini menggunakan analisis regresi linear ganda untuk menganalisis data yang diperoleh dari kuesioner-kuesioner berbentuk skala Likert. Hasil analisis menunjukkan bahwa kualitas kehidupan kerja secara signifikan berpengaruh terhadap kinerja. Hal ini dapat dilihat dari nilai R Square sebesar 0.313 dan nilai p sebesar 0.000 yang bermakna bahwa kualitas kehidupan kerja sebagai variabel bebas mempengaruhi variabel terikat yaitu kinerja sebesar $31 \%$, sedangkan sisanya dipengaruhi oleh variabel lain. Sementara itu, motivasi kerja tidak memiliki efek terhadap kinerja ( $p>0,05)$. Implikasi praktis dari penelitian ini adalah semakin tinggi kehidupan kerja karyawan, maka semakin tinggi pula kinerja karyawan. Hal ini selanjutnya dapat membuat karyawan lebih produktif dalam meningkatkan pelayanan kepada masyarakat.

Kata kunci: kinerja; kualitas kehidupan kerja; motivasi kerja

Received: June 13, 2017 Accepted: November 8, 2017

How to cite: Hasmalawati, N., \& Hasanati, N. (2017). Pengaruh kualitas kehidupan kerja dan motivasi kerja terhadap kinerja karyawan. MEDIAPSI, 3(2), 1-9.

doi:http://dx.doi.org/10.21776/ub.mps.2017.003.02.1

\section{Pendahuluan}

Dibalik berkembangnya sebuah perusahaan, terdapat peran dari kinerja karyawannya. Kinerja karyawan merupakan sekumpulan nilai dari kontribusi karyawan baik secara langsung maupun tidak langsung untuk mencapai tujuan organisasi (Borman \& Brush, 1993). Sementara menurut Simamora
(2002), kinerja merupakan hasil kerja yang dapat dicapai oleh seseorang atau sekelompok orang dalam suatu organisasi, sesuai dengan wewenang dan tanggung jawab masing masing, dalam rangka upaya mencapai tujuan organisasi bersangkutan secara legal, tidak melanggar hukum dan sesuai dengan moral maupun etika. Sehingga dapat disimpulkan bahwa kinerja optimal yang diberikan oleh karyawan akan memudahkan suatu organisasi untuk mencapai tujuan yang diinginkan.

Terdapat beberapa faktor yang dapat mempengaruhi optimalnya kinerja karyawan dalam perusahaan, di antaranya adalah 
motivasi. Motivasi kerja merupakan keadaan di mana usaha dan kemauan keras seseorang diarahkan kepada pencapaian hasil-hasil atau tujuan tertentu. Hasil-hasil yang dimaksud bisa berupa produktivitas, kehadiran, atau perilaku kerja kreatif lainnya. Motivasi kerja merupakan faktor pendorong sehingga dapat menghasilkan produktivitas dan kinerja yang optimal sesuai dengan tujuan organisasi (Sopiah, 2008). Kaitan motivasi kerja mempengaruhi kinerja karyawan dijelaskan oleh Handoko (2001) maupun penelitian yang dilakukan oleh Damayanti (2005) di mana motivasi kerja dapat berkorelasi positif dengan produktivitas karyawan. Hal ini juga didukung oleh penelitian Nawawi (2003) yang menyatakan bahwa suasana batin atau psikologis karyawan sebagai individu dalam masyarakat, organisasi, atau perusahaan dalam lingkungan kerjanya sangat besar pengaruhnya pada pelaksanaan pekerjaannya. Hal ini terlihat dalam semangat atas kerja yang menghasilkan kegiatan kerja sebagai kontribusi bagi pencapaian tujuan bisnis organisasi/perusahaan di tempatnya bekerja. Pada kenyataannya, kondisi psikologis tersebut sangat dipengaruhi oleh motivasi kerja yang mendorongnya. Oleh sebab itu, setiap karyawan memerlukan motivasi kerja yang tinggi agar bersedia melaksanakan pekerjaan secara bersemangat, bergairah, dan berdedikasi.

Penilaian kinerja karyawan dapat dilihat dari beberapa aspek, yakni kuantitas, kualitas, keandalan karyawan, dan kehadiran. Kuantitas merupakan banyaknya pekerjaan yang dapat dilakukan oleh seseorang dalam waktu satu hari kerja. Kualitas adalah ketaatan karyawan sesuai prosedur, disiplin, dan dedikasinya terhadap organisasi. Sedangkan keandalan karyawan merupakan kemampuan karyawan dalam melakukan pekerjaan yang mencakup konsistensi kinerja serta keandalan dalam pelayanan, akurat, benar, dan tepat. Sementara itu, kehadiran adalah keyakinan karyawan masuk kerja setiap hari dan sesuai dengan jam kerja yang sudah ditetapkan (Mathis \& Jackson, 2006).

Menurut Kusuma (2013), motivasi kerja karyawan didukung dari beberapa aspek seperti tercukupinya kebutuhan fisiologis karyawan, seperti makan atau minum atau sandang pangan, adanya rasa aman dari perusahaan yang berupa asuransi keselamatan atau kesehatan, adanya rasa sosial seperti tidak membedakan karyawan satu dengan karyawan lain, adanya rasa penghargaan diri dengan adanya bonus atau adanya pujian dari pimpinan, dan adanya kebebasan menyampaikan pendapat. Dengan adanya halhal tersebut, maka karyawan akan semakin bersemangat dalam bekerja sehingga kinerja karyawan akan semakin meningkat. Selanjutnya, dapat dipahami bahwa terciptanya motivasi kerja karyawan juga didukung oleh lingkungan kerja di perusahaan tersebut.

Perusahaan bertanggung jawab untuk memelihara kualitas kehidupan kerja atau disebut juga dengan Quality of Work Life (QWL) dan membina tenaga kerja agar bersedia memberikan sumbangannya secara optimal untuk mencapai tujuan perusahaan (Pruijt dalam Husnawati, 2006). Sojka (2014) mendefinisikan kualitas kehidupan kerja adalah sekumpulan fenomena dan atribut yang muncul dalam interaksi seseorang dan lingkungannya di tempat dia bekerja dalam sebuah organisasi. Sementara May, Lau, dan Johnson. (1999) mendefinisikannya sebagai keadaan kondusif di lingkungan kerja yang ditandai adanya kepuasan kerja pegawai karena mendapatkan gaji yang sesuai, jaminan 
kerja dan peluang untuk mengembangkan karir.

Menurut Davis dan Newstrom (dalam Alzeira, 2010) kualitas kehidupan kerja mengacu pada keadaan menyenangkan atau tidak lingkungan kerja bagi orang-orang yang terlibat di dalamnya. Hal yang utama dari kualitas kehidupan kerja adalah dampaknya bagi individu tersebut yaitu pekerjaan dapat menyebabkan orang menjadi lebih baik bukan orang-orang dapat mengerjakan pekerjaan lebih baik. Kualitas kehidupan kerja yang tinggi meliputi perasaan positif terhadap pekerjaannya karena suatu motivasi menunjukkan pekerjaan dan suatu keseimbangan yang baik antara kehidupan dan nilai-nilai pribadi serta terpenuhi kebutuhannya (Katzell, dkk. dalam Soedarnoto, 2004).

Nawawi (2003) juga menambahkan bahwa jika dilihat dari segi psikologis, manusia (seseorang) hanya melakukan suatu kegiatan yang menyenangkannya untuk dilakukan. Prinsip itu tidak menutupi kondisi bahwa dalam keadaan terpaksa seseorang mungkin saja melakukan sesuatu yang tidak disukainya. Dalam kenyataannya, kegiatan yang didorong oleh sesuatu yang tidak disukai berupa kegiatan yang terpaksa dilakukan, cenderung berlangsung tidak efektif dan tidak efisien. Oleh karena itu, manajemen sumber daya manusia menciptakan kondisi yang mampu mendorong setiap pekerja agar melaksanakan tugas-tugasnya dengan rasa senang dan puas. Adapun dengan kata lain, manajemen sebagai proses mendayagunakan orang lain untuk mencapai suatu tujuan hanya akan berlangsung efektif dan efisien jika para manajer mampu memotivasi para pekerja dalam melaksanakan tugas-tugas dan tanggung jawabnya.
Banyak penelitian tentang kualitas kehidupan kerja yang telah dilakukan dan hasilnya menunjukkan bahwa terdapat hubungan positif antara kualitas kehidupan kerja dengan beberapa variabel lain dalam organisasi, seperti motivasi kerja dan kepuasan karyawan (Fitriadi, 2012). Penelitian yang dilakukan oleh Samtica (2011) tentang hubungan komponen kualitas kehidupan kerja dengan motivasi kerja juga menunjukkan hasil yang signifikan. Sama halnya dengan Mochtar (2012) yang melakukan penelitian tentang kualitas kehidupan kerja dengan kinerja, yang menunjukkan hasil bahwa adanya hubungan positif yang signifikan.

Penelitian lain yang dilakukan oleh Zin (2004) tentang kualitas kehidupan kerja terhadap komitmen organisasional karyawan yang hasilnya menyatakan bahwa praktik kualitas kehidupan kerja mempengaruhi besarnya komitmen organisasional, terutama pada dimensi supervisi, upah, hubungan sosial, dan partisipasi. Hal ini selanjutnya dapat dipahami bahwa mengelola karyawan dengan menyediakan sarana dan prasarana dalam rangka mewujudkan lingkungan kerja dan iklim kerja yang kondusif diharapkan bisa mendorong karyawan untuk selalu berinovasi dan berkreasi. Hal tersebut juga dilakukan dengan membuat sistem yang fair dan struktur yang fleksibel dengan pembagian tugas, wewenang, dan tanggung jawab yang jelas dan manusiawi dengan memperhatikan kemampuan karyawan dan usahanya dalam mencapai tujuan karirnya (Husnawati, 2006).

Berdasarkan uraian di atas dapat disimpulkan bahwa jika sebuah organisasi ingin mencapai tujuan yang telah direncanakan, maka organisasi tersebut harus memperhatikan kebutuhan karyawan selama bekerja dan memotivasi karyawan dengan baik 
supaya memberikan kontribusinya terhadap sebuah organisasi melalui pencapaian kinerja yang optimal, sehingga menghasilkan keuntungan untuk keberlangsungan sebuah organisasi.

Penelitian ini bertujuan untuk mengetahui pengaruh antara kualitas kehidupan kerja dan motivasi kerja terhadap kinerja karyawan. Hasil penelitian ini diharapkan dapat menambah khazanah ilmu pengetahuan psikologi khususnya di bidang psikologi industri dan organisasi serta menjadi referensi kepada pimpinan atau atasan agar lebih memperhatikan kualitas kehidupan kerja dan motivasi kerja supaya karyawan termotivasi dan memberikan kinerja yang optimal dalam bekerja untuk mewujudkan tujuan organisasi. Sementara itu, hipotesis yang diajukan dalam penelitian ini adalah terdapat pengaruh kualitas kehidupan kerja terhadap kinerja, terdapat pengaruh motivasi kerja terhadap kinerja, dan juga terdapat kualitas kehidupan kerja dan motivasi kerja terhadap kinerja karyawan.

\section{Metode}

\section{Desain Penelitian}

Berdasarkan permasalahan dan tujuan penelitian yang akan dicapai, maka jenis penelitian ini adalah penelitian penjelasan (explanatory research). Explanatory research merupakan penelitian yang menjelaskan hubungan kausal antara variabel bebas (independent variable) yaitu variabel kualitas kehidupan kerja dan motivasi kerja terhadap variabel terikat (dependent variable) yaitu kinerja karyawan melalui pengajuan hipotesis dengan menggunakan data-data yang sama (Singarimbun \& Effendi, 1995).

\section{Partisipan}

Subjek dalam penelitian ini adalah Kader
TB-HIV yang berjumlah 50 orang, terdiri dari 36 orang perempuan dan 14 orang laki-laki yang usianya berkisar antara 18-63 tahun.

\section{Instrumen Penelitian}

Adapun instrumen penelitian yang digunakan pada penelitian ini meliputi:

1. Skala yang digunakan untuk mengukur kinerja diadaptasi dari Lubis (2008) yang disusun berdasarkan teori dari Prawirosentono (1999) tentang dimensi kinerja yang dirangkum menjadi lima dimensi, yaitu kuantitas kerja, kualitas kerja, kerja sama, pemahaman terhadap tugas, inisiatif, disiplin, dan tanggung jawab serta keandalan.

2. Skala yang digunakan untuk mengukur motivasi kerja dikembangkan dari Indrarini (2009) berdasarkan dimensi-dimensi motivasi kerja, yaitu dorongan internal yang meliputi prestasi, pemgakuan, dan tanggung jawab, serta dorongan eksternal yang meliputi promosi dan pertumbuhan.

3. Skala yang digunakan untuk mengukur kualitas kehidupan kerja dikembangkan dari Anditasari (2011) berdasarkan teori dari Cascio (dalam Nawawi, 2006) tentang sembilan unsur yang menjadi komponen penting dalam kualitas kehidupan kerja, yaitu partisipasi karyawan, pengembangan karir, penyelesaian konflik, komunikasi, kesehatan kerja, keselamatan kerja, lingkungan yang aman, kompensasi yang layak, dan kebanggaan.

Kuesioner kinerja terdiri dari 13 aitem dengan nilai Cronbach Alpha 0.887. Akan tetapi, setelah diuji kembali, terdapat 9 butir yang valid dengan Cronbanch Alpha 0.765. Kuesioner kualitas kehidupan kerja terdiri dari 30 butir dengan nilai Cronbach Alpha 0.955. Setelah diuji kembali, ketiga puluh butir 
tersebut valid dengan Cronbach Alpha 0.955. Sementara itu, motivasi kerja yang awalnya terdiri dari 20 butir dengan nilai Cronbach Alpha 0.920, setelah diuji kembali hanya terdapat 9 butir yang valid dengan Cronbach Alpha 0.841.

\section{Analisis Data}

Analisis yang digunakan dalam penelitian ini yaitu analisis regresi ganda. Analisis tersebut dilakukan untuk mengetahui adanya pengaruh kualitas kehidupan kerja dan motivasi kerja terhadap kinerja. Sesuai dengan hipotesis dan tujuan penelitian ini, maka untuk mengetahui pengaruh, data yang diperoleh akan diuji terlebih dahulu dengan menggunakan uji asumsi syarat yaitu uji normalitas dan uji linieritas.

\section{Hasil}

Sebelum menguji analisis regresi ganda untuk melihat seberapa besar pengaruh variabel bebas terhadap variabel terikat, peneliti terlebih dahulu melakukan uji asumsi syarat yaitu uji normalitas dan uji linieritas. Uji normalitas yang dilakukan menunjukkan bahwa data berdistribusi normal karena nilai $p>0.05$. Setelah melakukan uji normalitas, peneliti melakukan uji asumsi syarat yang kedua yaitu uji linieritas untuk melihat adanya hubungan yang linier di antara ketiga variabel. Hasil uji linieritas menunjukkan bahwa hubungan kinerja dan kualitas kehidupan kerja memiliki hubungan yang linier karena nilai $\mathrm{p}<0.05$, sedangkan kinerja dengan motivasi kerja memiliki hubungan yang tidak linier karena nilai $\mathrm{p}>0.05$.

Setelah uji asumsi terpenuhi, maka selanjutnya peneliti melakukan uji regresi untuk mengetahui banyaknya sumbangan atau pengaruh variabel bebas yaitu kualitas kehidupan kerja dan motivasi kerja terhadap variabel terikat yaitu kinerja. Hasil analisis menunjukkan bahwa kualitas kehidupan kerja sangat berpengaruh terhadap kinerja. Hal ini dilihat dari nilai $\mathrm{p}<0.05$. Nilai $R$ Square sebesar 0.313 menunjukkan bahwa kualitas kehidupan kerja sebagai variabel bebas mempengaruhi variabel terikat yaitu kinerja sebesar $31 \%$, sedangkan sisanya sebesar $69 \%$ dipengaruhi oleh variabel lain. Berbeda dengan kualitas kehidupan kerja, motivasi kerja memiliki nilai $\mathrm{p}>0.05$ yang menunjukkan bahwa motivasi kerja tidak berpengaruh terhadap kinerja. Hasil analisis uji regresi dijabarkan dalam Tabel 1.

Tabel 1

Hasil Analisis Uji Regresi QWL \& Motivasi terhadap Kinerja

\begin{tabular}{clccc}
\hline No. & \multicolumn{1}{c}{ Variabel } & R & $\mathbf{R}^{\mathbf{2}}$ & $\mathbf{p}$ \\
\hline 1 & $\begin{array}{l}\text { QWL \& } \\
\text { Kinerja }\end{array}$ & .559 & .313 & .000 \\
2 & $\begin{array}{l}\text { Motivasi Kerja } \\
\text { \& Kinerja }\end{array}$ & .566 & .320 & .489 \\
\hline
\end{tabular}

Ketika diuji secara bersamaan, variabel kualitas kehidupan kerja dan motivasi kerja memiliki pengaruh yang signifikan terhadap variabel kinerja dengan nilai $\mathrm{p}<0.05$. Nilai $R$ Square sebesar 0.320 menunjukkan bahwa kualitas kehidupan kerja dan motivasi kerja sebagai variabel bebas mempengaruhi variabel terikat yaitu kinerja sebesar $32 \%$, sedangkan sisanya $68 \%$ dipengaruhi oleh variabel lain. Hasil analisis selengkapnya dijabarkan dalam Tabel 2.

Tabel 2

Hasil Analisis Regresi QWL \& Motivasi Kerja Terhadap Kinerja Saat Diuji Secara Bersamaan

\begin{tabular}{cccc}
\hline \multicolumn{1}{c}{ Variabel } & $\mathbf{R}$ & $\mathbf{R}^{2}$ & $\mathbf{p}$ \\
\hline $\begin{array}{l}\text { QWL \& Motivasi } \\
\text { terhadap Kinerja }\end{array}$ & .566 & .320 & .000 \\
\hline
\end{tabular}

\section{Diskusi}

Penelitian ini menunjukkan bahwa 
hanya kualitas kehidupan kerja yang mempengaruhi kinerja sedangkan motivasi kerja sebaliknya. Semakin tinggi kualitas kehidupan kerja, maka semakin tinggi pula kinerja karyawan. Penelitian ini sejalan dengan penelitian Arifin (2012) yang berpendapat bahwa kualitas kehidupan kerja merumuskan setiap proses kebijakan yang diputuskan oleh perusahaan merupakan sebuah respon atas apa yang menjadi keinginan dan harapan karyawan mereka. Hal itu kemudian diwujudkan dengan berbagi persoalan dan menyatukan pandangan mereka (perusahaan dan karyawan) ke dalam tujuan yang sama yaitu peningkatan kinerja karyawan dan perusahaan.

Pendapat Arifin (2012) yang berkaitan dengan teori kualitas kehidupan kerja sebelumnya dikemukakan oleh Wayne (dalam Yusuf, 2010), yang menyatakan bahwa pimpinan perusahaan perlu menyikapi dengan sebaik-baiknya makna dari konsep Quality of Work Life dengan tujuan agar hubungan antara pihak manajemen dengan karyawan dapat berjalan dengan baik yang bermuara pada peningkatan kinerja. Adanya kualitas kehidupan kerja juga menumbuhkan keinginan para karyawan untuk tetap tinggal dan bertahan di dalam organisasi. Hasil penelitian ini sesuai dengan penelitian yang dilakukan oleh Anditasari (2011) dan Mahardikawanto (2013) yang menyatakan bahwa kualitas kehidupan kerja karyawan mempengaruhi kinerja karyawan. Apabila kualitas kehidupan kinerja karyawan ditingkatkan maka kinerja karyawan juga akan meningkat.

Perusahaan yang kurang memperhatikan faktor kualitas kehidupan kerja akan sulit mendapatkan atau mempertahankan pekerja yang sesuai dengan kebutuhan perusahaan, bahkan akan sulit membangkitkan kinerja karyawan yang sudah ada. Oleh sebab itu, perusahaan tersebut akan menghadapi kondisi perpindahan pekerja, karena karyawan lebih memilih untuk bekerja di tempat atau perusahaan lain yang menerapkan berbagai faktor kualitas kehidupan kerja yang lebih menjanjikan.

Adapun motivasi kerja tidak mempengaruhi kinerja karyawan berdasarkan hasil penelitian ini. Hal ini sejalan dengan penelitian yang dilakukan oleh Dhermawan, dkk. (2012) yang menyatakan bahwa motivasi tidak berpengaruh signifikan terhadap kinerja. Selain itu, penelitian yang dilakukan oleh Brahmasari dan Agus (2008) juga menyatakan bahwa motivasi kerja tidak berpengaruh terhadap kinerja. Belum optimalnya kerja seorang karyawan dibatasi oleh adanya kebijakan atasan misalnya berhubungan dengan waktu lembur, di mana karyawan yang telah terpuaskan kebutuhannya merasa bahwa manajemen telah memberikan penghargaan kepada dirinya sehingga dia merasa harus bekerja dengan profesional. Hal ini berarti bahwa apabila terdapat pekerjaan yang melekat pada dirinya hingga jam kerja normal telah berakhir, karyawan tersebut bermaksud untuk menyelesaikannya karena dedikasi dan loyalitas terhadap pekerjaannya meskipun tidak diperhitungkan sebagai lembur. Akan tetapi, pihak manajemen menentukan bahwa sesuai ketentuan yang ada hal tersebut tidak diperkenankan, sehingga akhirnya karyawan tersebut akan menyelesaikan pada hari berikutnya. Hal inilah yang salah satunya menjadi suatu pertimbangan dan alasan bahwa motivasi kerja tidak berpengaruh signifikan terhadap kinerja perusahaan (Brahmasari dan Agus, 2008).

Mangkunegara (2005) mengemukakan bahwa terdapat dua teknik untuk memotivasi kinerja pegawai, yaitu (1) teknik pemenuhan 
kebutuhan pegawai, yang berarti bahwa pemenuhan kebutuhan pegawai merupakan aspek fundamental yang mendasari perilaku kerja; (2) teknik komunikasi persuasif, dengan salah satu tekniknya yaitu memotivasi kerja pegawai yang dilakukan dengan cara mempengaruhi pegawai secara ekstra logis. Teknik ini dirumuskan dengan istilah "AIDDAS" yaitu Attention (perhatian), Interest (minat), Desire (hasrat), Decision (keputusan), Action (aksi atau tindakan), dan Satisfaction (kepuasan). Dalam penerapannya, pemimpin harus memberikan perhatian terlebih dahulu kepada pegawainya tentang pentingnya tujuan dari suatu pekerjaan agar timbul minat pegawai terhadap pelaksanaan kerja. Jika telah timbul minat, maka hasratnya akan menjadi kuat untuk mengambil keputusan dan melakukan tindakan kerja dalam mencapai tujuan yang diharapkan oleh pemimpin. Dengan demikian, pegawai akan bekerja dengan motivasi tinggi dan merasa puas terhadap hasil kerjanya.

Penelitian ini memiliki beberapa keterbatasan, di antaranya adalah sebagian responden mungkin kurang memahami pernyataan dari kuesioner yang diberikan, sehingga kurang mengukur keadaan diri subjek sebenarnya. Hal tersebut juga dapat mengakibatkan kebenaran jawaban dari responden bukan cerminan dari keadaan diri responden yang sebenarnya karena mengisi kuisioner secara asal-asalan dan takut dinilai tidak baik oleh peneliti.

Hasil penelitian ini menunjukkan bahwa kualitas kehidupan kerja berpengaruh signifikan terhadap kinerja dengan nilai $\mathrm{p}<0.05$. Nilai R Square 0.313 menunjukkan bahwa kualitas kehidupan kerja mempengaruhi kinerja sebesar $31 \%$, sedangkan sisanya $69 \%$ dipengaruhi oleh variabel lain. Tetapi lain halnya dengan motivasi kerja, dengan nilai $\mathrm{p}>0.05$, hal ini menunjukkan bahwa motivasi kerja tidak berpengaruh terhadap kinerja. Namun demikian, ketika diuji secara bersamaan, variabel kualitas kehidupan kerja dan motivasi kerja memiliki pengaruh yang signifikan terhadap kinerja dengan nilai $\mathrm{p}<0.05$ dan nilai $\mathrm{R}$ Square sebesar 0.320 menunjukkan bahwa kualitas kehidupan kerja dan motivasi kerja mempengaruhi kinerja sebesar 32\%, sedangkan sisanya $68 \%$ dipengaruhi oleh variabel lain.

Berdasarkan penelitian ini, terdapat saran praktis bagi perusahaan. Perusahaan disarankan untuk memperhatikan QWL dengan baik, karena karyawan akan merasa nyaman dan betah bekerja di suatu perusahaan tanpa ada niat untuk keluar atau mengundurkan diri. Perusahaan sebaiknya juga menerapkan teknik dalam memotivasi karyawan, karena hal ini dapat menyebabkan karyawan akan merasa termotivasi dalam bekerja dan memberikan kinerja yang optimal untuk mencapai tujuan perusahaan yang telah dirumuskan sebelumnya.

Bagi penelitian selanjutnya, disarankan agar menambah variabel lain yang berpengaruh sehingga dapat diketahui variabel yang paling banyak mempengaruhi kinerja atau menganalisis satu persatu aspek dari kualitas kehidupan kerja yang paling banyak mempengaruhi kinerja karyawan agar bisa lebih ditingkatkan lagi. Hal ini dilakukan agar pimpinan atau atasan dapat meningkatkan aspek yang paling mempengaruhi kinerja karyawan yang mengakibatkan optimalnya kinerja yang diberikan. 


\section{Daftar Pustaka}

Alzeira, E. R. (2010). Hubungan komponen kualitas kehidupan kerja (quality of work life) dengan motivasi kerja pegawai RS Tugu Ibu. Skripsi. Universitas Indonesia: Fakultas Kesehatan Masyarakat.

Anditasari, D. (2011). Analisis faktor-faktor Quality of Work Life (QWL) sebagai pendukung peningkatan kinerja karyawan. Skripsi. Institut Pertanian Bogor: Fakultas Ekonomi dan Manajemen.

Arifin, N. (2012). Analisis kualitas kehidupan kerja, kinerja, dan kepuasan kerja pada CV. Duta Senenan Jepara. Journal Economia, 8(1), 11-21.

Borman, W. C., \& Brush, D. H. (1993). More progress toward a taxonomy of managerial performance requirements. Human Performance, 6(1), 1-21.

Brahmasari, I. A., \& Agus, S. (2008). Pengaruh motivasi kerja, kepemimpinan, dan budaya organisasi terhadap kepuasan kerja karyawan serta dampaknya pada kinerja perusahaan (Studi kasus pada PT. Pei Hai International Wiratama Indonesia). Jurnal Manajemen dan Kewirausahaan, 10(2).

Damayanti, R. (2005). Pengaruh motivasi kerja karyawan terhadap produktivitas kerja karyawan CV. Bening Natural Furniture di Semarang. Skripsi. Universitas Negeri Semarang: Fakultas Ilmu Sosial.

Dhermawan, A. A. N. B., Sudibya, I. G. A., \& Utama, I. W. M. (2012). ha Jurnal Manajemen, Strategi Bisnis, dan Kewirausahaan, 6(2).
Fitriadi, B. Y. (2012). Analisis pengaruh kualitas kehidupan kerja terhadap motivasi kerja dan kinerja karyawan PT. Bank Muamalat Indonesia Jember. Skripsi. Universitas Jember: Fakultas Ekonomi.

Handoko, T. H. (2001). Manajemen Personalia dan Sumber Daya Manusia. Yogyakarta: BPFE Press.

Husnawati, A. (2006). Analisis pengaruh kualitas kehidupan kerja terhadap kinerja karyawan dengan komitmen dan kepuasan kerja sebagai intervening variable: Studi pada Perum Pegadaian Kanwil VI Semarang. Tesis. Universitas Diponegoro: Program Studi Magister Manajemen.

Indrarini. (2009). Pengaruh motivasi dan kepuasan kerja terhadap kinerja dosen akademi swasta di Kota Semarang. Tesis. Universitas Negeri Semarang: Program Studi Manajemen Pendidikan.

Kusuma, A. A. (2013). Pengaruh motivasi dan lingkungan kerja terhadap kinerja karyawan Hotel Muria Semarang. Skripsi. Universitas Negeri Semarang: Fakultas Ekonomi.

Lubis, K. A. (2008). Pengaruh pelatihan dan motivasi kerja terhadap kinerja karyawan. Tesis. Universitas Sumatera Utara.

Mahardikawanto. (2013). Pengaruh disiplin kerja, lingkungan kerja, dan kualitas kehidupan kerja terhadap kinerja karyawan RSUD Dr. M. Ashari Pemalang. Skripsi. Universitas Negeri Semarang: Fakultas Ekonomi.

Mangkunegara, A. P. (2005). Manajemen Sumber Daya Manusia Perusahaan 
Cetakan Keenam. Bandung: Remaja Rosdakarya.

Mathis, R. L., \& Jackson, J. H. (2006). Manajemen Sumber Daya Manusia Buku 1. Jakarta: Salemba Empat.

May, B. E., Lau, R. S. M., \& Johnson, S. K. (1999). A longitudinal study of quality of work life and business performance. South Dakota Business Review, 58(2), 17.

Mochtar, H. (2012). Hubungan komponen quality of work life dengan kinerja bidan. Tesis. Universitas Indonesia: Fakultas Kesehatan Masyarakat.

Nawawi, H. (2003). Manajemen Sumber Daya Manusia untuk Bisnis yang Kompetetif. Yogyakarta: Gajah Mada University Press.

Nawawi, H. (2006). Evaluasi dan Manajemen Kinerja di Lingkungan Perusahaan dan Industri. Yogyakarta: Gadjah Mada University Press.

Prawirosentono, S. (1999). Kebijakan Kinerja Karyawan Kiat Membangun Organisasi Kompetitif Menjelang Perdagangan Bebas Dunia Edisi Pertama. Yogyakarta: BPFE.

Samtica, S. (2011). Hubungan komponen kualitas kehidupan kerja atau quality of work life dengan motivasi kerja perawat pelaksana di RS Haji Jakarta. Skripsi. Universitas Indonesia: Fakultas Kesehatan Masyarakat.

Simamora, H. (2002). Manajemen Sumber Daya Manusia. Yogyakarta: STIE YKPN.

Singarimbun, M., \& Effendi, S. (1995).

Metode Penelitian Survey. Jakarta:

LP3ES.
Soedarnoto, L. F. N. (2004). Peningkatan Usaha dalam Kualitas Kehidupan Kerja. Jakarta: Fakultas Keguruan dan Ilmu Pendidikan Unika Atma Jaya.

Sojka, L. (2014). Specification of the Quality of Work Life characteristics in the Slovak economic environment. Sociologia, 46(3), 283-299.

Sopiah. (2008). Perilaku Organisasional. Yogyakarta: Andi Offset.

Zin, R. M. (2004). Perception of professional engineers toward quality of work life and organizational commitment. Gadjah Mada International Journal of Business, 6(3), 32-33. 